\title{
Effects of Biodiesel to Soil
}

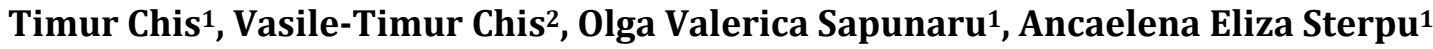 \\ ${ }^{1}$ Chemical and Chemical Engineering Department, Ovidius University Constanta, Constanta, Romania \\ ${ }^{2} \mathrm{Ph} . \mathrm{D}$. School, Oradea University, Oradea, Romania \\ Email: timur.chis@gmail.com
}

How to cite this paper: Chis, T., Chis, V.-T., Sapunaru, O.V. and Sterpu, A.E. (2021) Effects of Biodiesel to Soil. Journal of Environmental Protection, 12, 1009-1018. https://doi.org/10.4236/jep.2021.1212059

Received: November 3, 2021

Accepted: December 4, 2021

Published: December 7, 2021

Copyright $\odot 2021$ by author(s) and Scientific Research Publishing Inc. This work is licensed under the Creative Commons Attribution International License (CC BY 4.0).

http://creativecommons.org/licenses/by/4.0/

\begin{abstract}
In all studies that analyzed biodiesel pollution effect of this compound on animals and especially marine animals. Biodiesel (methanol and sodium hydroxide) as to be taken into account. Less emphasis is placed on biodiesel pollution of soils and waters (which can occur in the event of an environmental accident), which is considered a biodegradable product. But an accidental pollution due to the derailment of a freight train (August 12, 2020 on the CF line the Bucharest-Craiova highway, in the area of the CF bridge from Cârcea locality, Dolj county, Romania), confirmed the lack of knowledge in this field, as well as the way of depollution and restoration of the environment. This article describes how to pollute the soil with biodiesel, as well as the mathematical equations that describe this phenomenon.
\end{abstract}

\section{Keywords}

Biodiesel, Accidental Pollution, Soil, Numerical Modeling

\section{Introduction}

Biofuels have recently been increasingly used in the auto transport industry, both to reduce greenhouse gas emissions from fuel combustion in heat engines and to introduce environmentally friendly renewable fuels in conventional engines.

But green fuels are usually produced in refineries close to agricultural areas (where biofuel plants are located).

Given that in order to deliver conventional fuels mixed with organic ones, mixing facilities are needed, there is a need to transport this environmentally friendly fuel from biofuel refineries to petroleum product depots.

The transport is carried out by car, rail and naval, which in many cases also occur by accidental pollution, due to the leakage of transport facilities, as well as accidental pollution. 
In the present paper, we sought to analyze the effect of biodiesel on the soil, by determining the sorption capacity of soils and especially by establishing a rehabilitation time of the soil affected by this pollution.

The effect of biodiesel and diesel on the properties of soils affected by accidental pollution is also shown.

The first research in the field of biodiesel pollution in 1995, when Nalissa Farrah Khan published a doctoral thesis: "A comparison of acute toxicity of biodiesel, biodiesel blends and diesel on aquatic organisms" [1].

The author states that diesel leaks and biodiesel leaks can have harmful effects on the aquatic environment by decreasing by $10 \%$ the activity of microorganisms in the water.

The effect of the analyzed fuels (clean diesel, biofuel and diesel mixtures) on O. mykiss and Magna D. mollusc species was assessed using acute toxicity tests.

For Magda D., a high mortality was determined for diesel (over $80 \%$ ) and low for biodiesel (maximum 65\%). It has also been observed that on O. mykiss species, at a concentration below $100 \mathrm{ppm}$, biodiesel has reduced effects on mortality.

Another research direction was dedicated to the analysis of the biodegradability of biodiesel.

Thus, C. L. Peterson and Gregory Möller observed that any type of biodiesel degrades in a maximum of 32 days [2].

M. Hawrot-Paw, A. Wijatkowski and M. Mikiciuk analyzed the phytotoxicity of biodiesel and diesel through the test of germination of soils polluted with diesel and biofuel [3].

They also analyzed the effect of fuel on soil microorganisms and plant development [4] [5].

Research has shown that there are plant species that are resistant to biodiesel pollution.

Usually biodiesel reduces the number of heterotrophic microorganisms and stimulates the number of microorganisms needed to decompose biomass. Biodiesel had a small influence on the biometric and physiological parameters of plants.

Plant growth has been observed in biodiesel pollution [6] [7].

\section{Experimental Methodology}

In order to analyze the behavior of pollutants (diesel and biodiesel) on the soil, a set of experiments was performed.

In the first stage we determined the density with the device based on the frequency of the tube [8] according to ASTM D1298-99 (2005) [9].

I also determined the viscosity according to ASTM D1665-98 (2009) [10], with $\mathrm{U}$ tube viscosimeter [11].

Subsequently, the apparent densities of the soil types that are subject to weighing pollution were determined whit internal solution of measuring. 
For the study of the displacement of pollutants in the soil and the depollution of polluted soils by the method of absorbent crops, own working standards were created.

Temperature of the soil, biodiesel and diesel for experiments is $20^{\circ} \mathrm{C}$.

The purpose of this study was to establish mathematical relationships to describe the behavior of soil to biodiesel and diesel pollution. The density and viscosity of the two products were determined at $20^{\circ} \mathrm{C}$ and transformed at $15^{\circ} \mathrm{C}$.

The density of diesel is $0.8414 \mathrm{~kg} / \mathrm{m}^{3}$ and the viscosity is $1.76^{\circ} \mathrm{E}$. The density of biodiesel is $0.8808 \mathrm{~kg} / \mathrm{m}^{3}$ and the viscosity is $1.80^{\circ} \mathrm{E}$. The apparent densities of the soils used in the study were performed by taking a sample with a probe having a volume of $50 \mathrm{ml}$ samples were taken with the probe device, manufactured by author from Figure 1, and then weighed with the analytical balance. For the study, land from the Ramnicu de Jos area (Constanta County, Romania) was used, where there is a biodiesel production unit. Samples were also taken from a flower soil (composed of dry peat mixed with loess in $50 \%$ percent) and biodegradable absorbent (peat treated by drying). The following values were determined (at $50 \mathrm{ml}$ sample collected).

Apparent soil density $1.350 \mathrm{~kg} / \mathrm{m}^{3}$ to $20^{\circ} \mathrm{C}$.

Apparent density of flower soil $0.444 \mathrm{~kg} / \mathrm{m}^{3}$ to $20^{\circ} \mathrm{C}$.

Apparent density of dry peat $0.121 \mathrm{~kg} / \mathrm{m}^{3}$ to $20^{\circ} \mathrm{C}$.

The procedure used to determine the displacement of pollutants in the soil was to establish a correlation between the amount of fluid injected into the soil and the absorption capacity of the soil.

By this method the retention curve of the absorbed product was determined with device manufactured by author (Figure 2 and Figure 3 ).

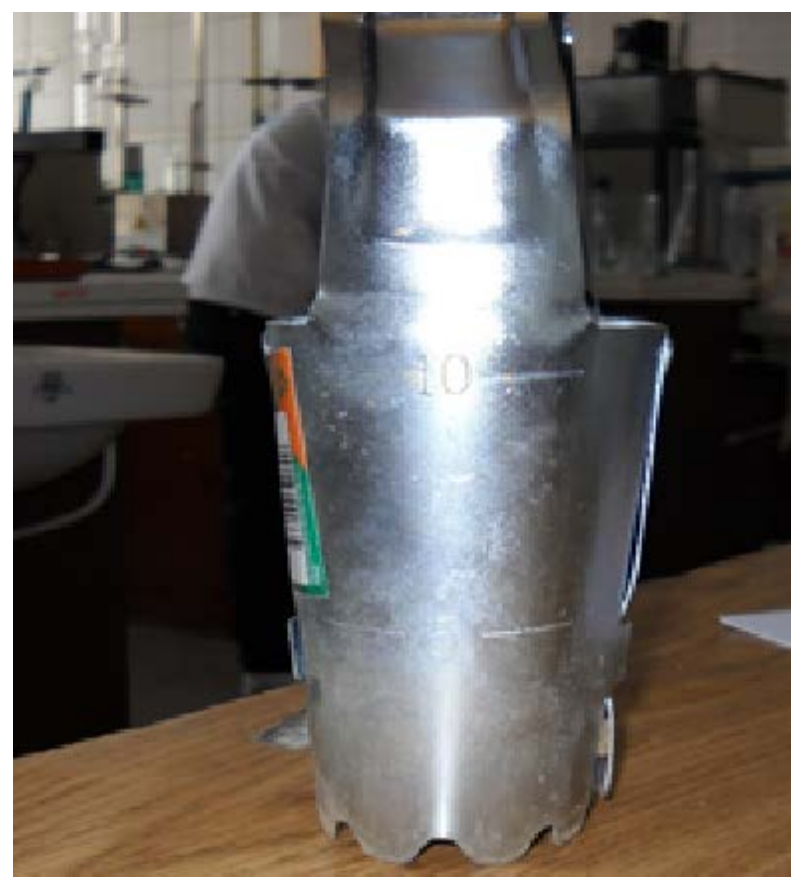

Figure 1. Soil sampling device (device made by author). 


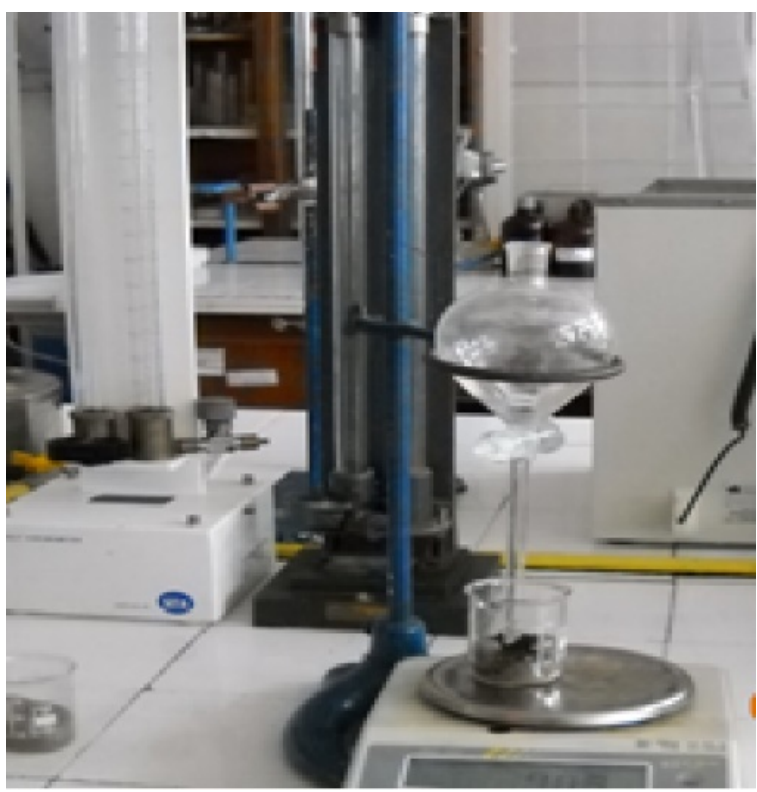

Figure 2. Plant for the study of soil adsorption of pollutants (device made by author).

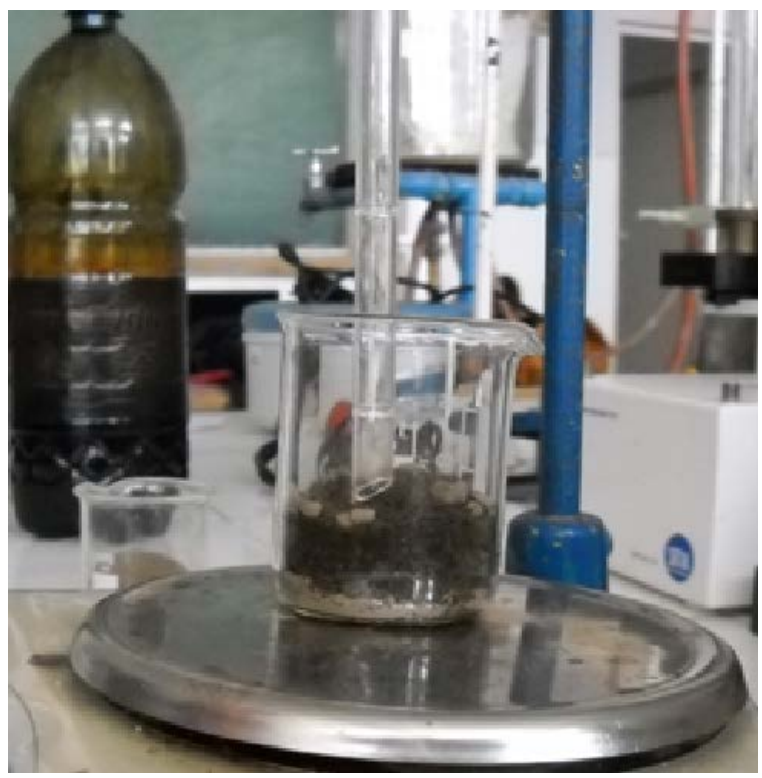

Figure 3. The mode of sorption of pollutants in the soil (device made by author).

\section{Sorption Capacity of Soil}

After performing the experiment under the same conditions, we managed to determine the adsorption capacity of the pollutant by the soil (Table 1 and Table 2).

The experiment temperature is $20^{\circ} \mathrm{C}$.

This is how we determined:

1) Soil retention (sorption) capacity to $20^{\circ} \mathrm{C}$, of the Ramnicu de Jos area due to biodiesel pollution (Figure 4). 
Table 1. Soil sorption (retention) capacity equation (to $20^{\circ} \mathrm{C}$ of determinations experiments).

\begin{tabular}{lll}
\hline \multirow{2}{*}{ Soil type } & relationship & \\
\cline { 2 - 3 } & Equation & $\mathrm{R}^{2}$ \\
\hline Ramnicu de Jos soil, biodisel absortion & $\mathrm{y}=0.0043 \mathrm{x}^{3}-0.1736 \mathrm{x}^{2}+2.7258 \mathrm{x}-2 \mathrm{E}-11$ & 1 \\
Flower soil absortion & $\mathrm{y}=-0.0011 \mathrm{x}^{3}+0.0376 \mathrm{x}^{2}+1.0298 \mathrm{x}-6 \mathrm{E}-12$ & 1 \\
Adsorber absortion & $\mathrm{y}=-0.0011 \mathrm{x}^{3}+0.0597 \mathrm{x}^{2}+0.4603 \mathrm{x}-5 \mathrm{E}-12$ & 1 \\
Ramnicu de Jos soil, disel absortion & $\mathrm{y}=0.0873 \mathrm{x}^{2}+0.5907 \mathrm{x}+4 \mathrm{E}-14$ & 1 \\
\hline
\end{tabular}

Table 2. Maximum soil sortion (retention) capacity (to $20^{\circ} \mathrm{C}$ of determinations experiments).

\begin{tabular}{cc}
\hline Soil type & Quantity of polluants dissolved in soil \\
\cline { 2 - 2 } & $\mathrm{ml}$ \\
\hline Ramnicu de Jos soil, biodisel adsortion & 34 \\
Flower soil biodiesel adsortion & 34 \\
Natural sorber biodiesel adsortion & 45 \\
Ramnicu de Jos soil, disel adsortion & 9.4 \\
\hline
\end{tabular}

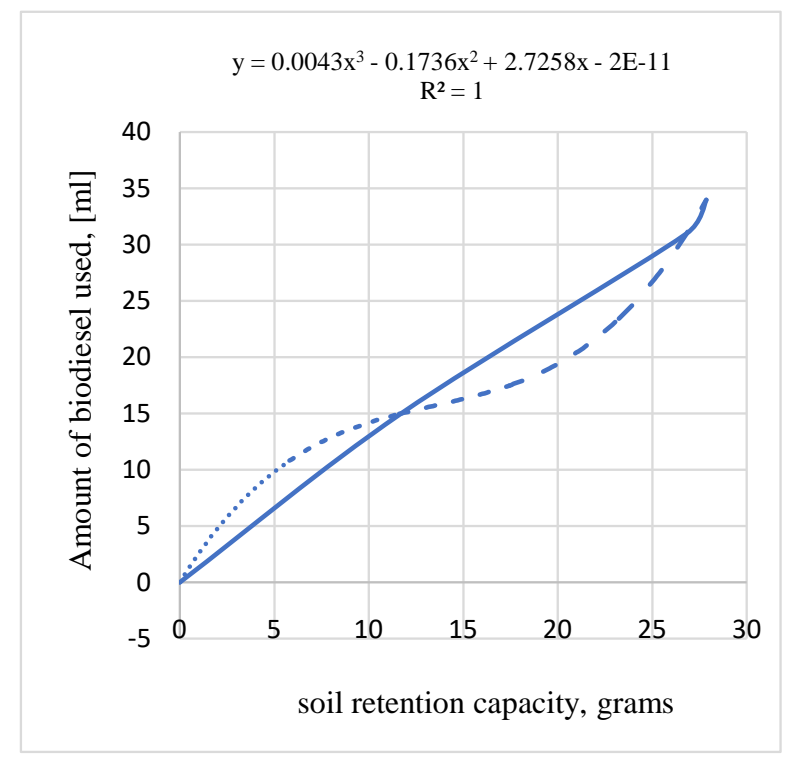

Figure 4. Soil retention (sortion) capacity in the Ramnicu de Jos area due to biodiesel pollution (to $20^{\circ} \mathrm{C}$ of determinations experiments).

2) The retention(sorption) capacity of flower soil to biodiesel pollution (Figure 5).

3) The retention capacity (sorption) of the natural sorption (dry peat) for biodiesel pollution (Figure 6)

4) Râmnicu de Jos type soil retention (sorption) capacity for diesel pollution (Figure 7). 


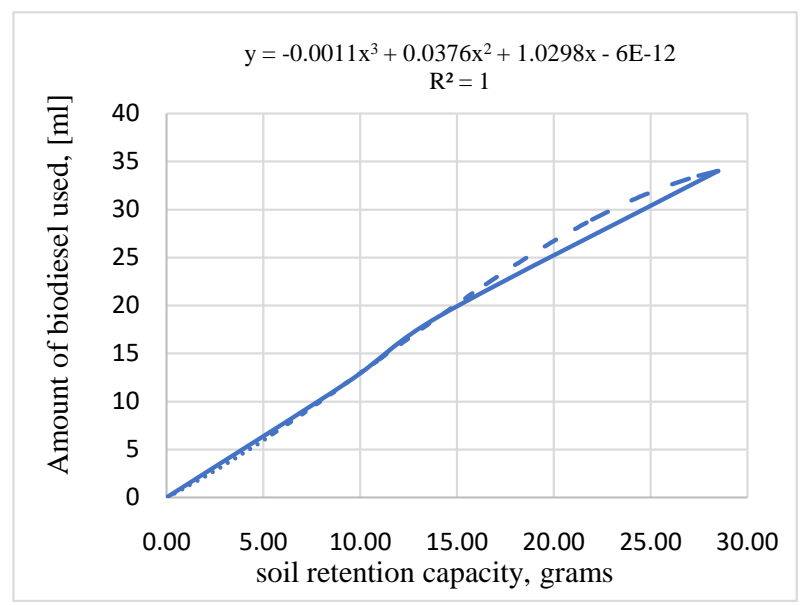

Figure 5. The retention (sorption) capacity of flower soil to biodiesel pollution (to $20^{\circ} \mathrm{C}$ of determinations experiments).

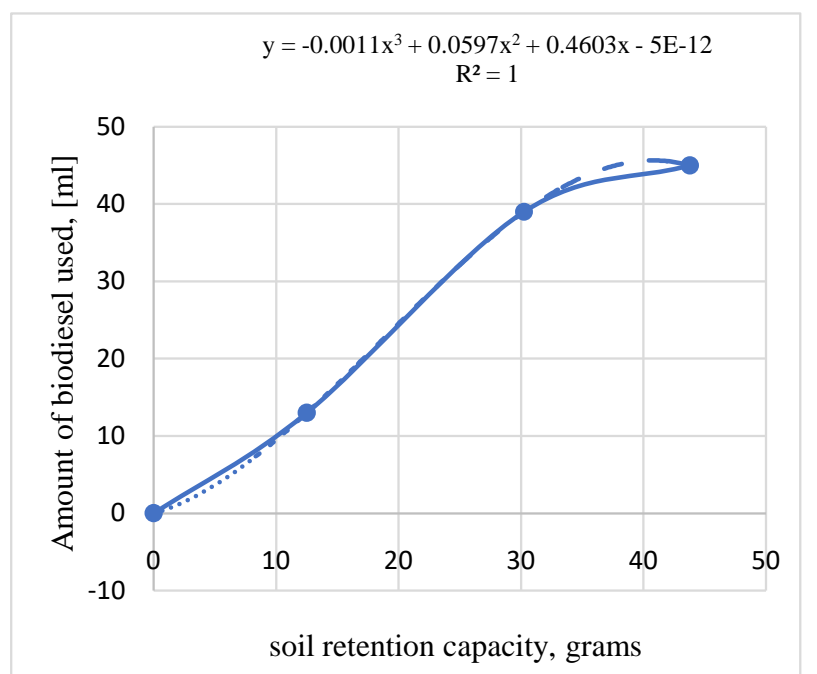

Figure 6. The retention (sorption) capacity of the absorber (dry peat) for biodiesel pollution (to $20^{\circ} \mathrm{C}$ of determinations experiments).

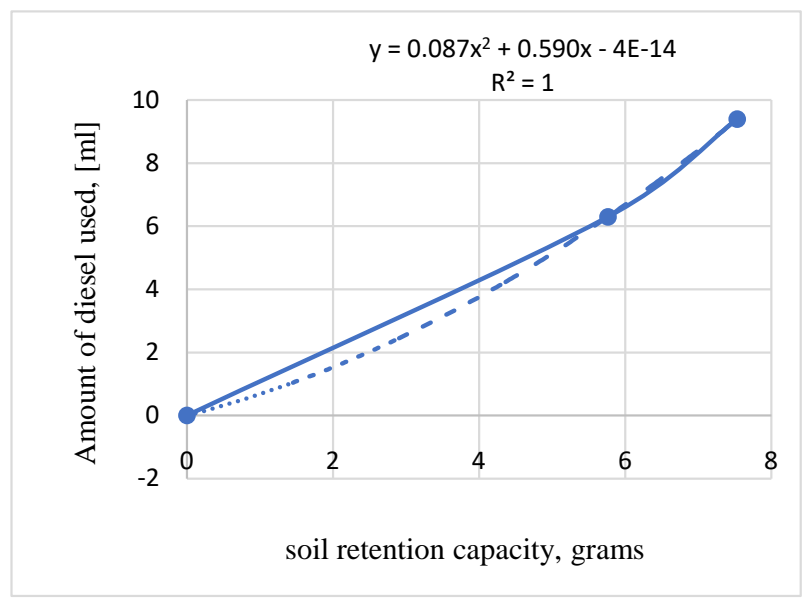

Figure 7. Râmnicu de Jos type soil retention (sortion) capacity for diesel pollution (to $20^{\circ} \mathrm{C}$ of determinations experiments). 


\section{Phytoremediation of Soil Polluted with Diesel and Biodiesel}

To see how the soil polluted with biodiesel behaves in phytoremediation were planted in three flower pots filled with:

- unpolluted soil,

- soil polluted with biodiesel ( $15 \mathrm{ml}$ of biodiesel),

- flower soil treated with biodiesel ( $15 \mathrm{ml}$ of biodiesel),

Pots were planted in flower (Tagetes patula) pots with a volume of 40 grams to $20^{\circ} \mathrm{C}$ (Figure 8 ).

The flowers were monitored for 1 month between 4.4.2021-5.4.2021, according to international flower control standards ( 1 month and of $20^{\circ} \mathrm{C}$ ) (Figure 9, Figure 10).

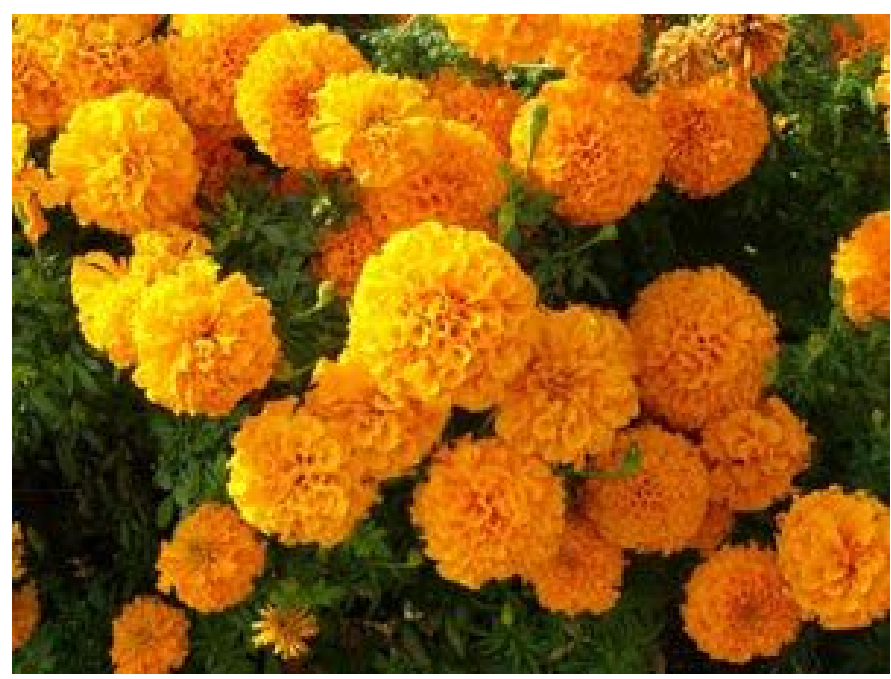

Figure 8. Flower used in soil remediation (Tagetes patula).

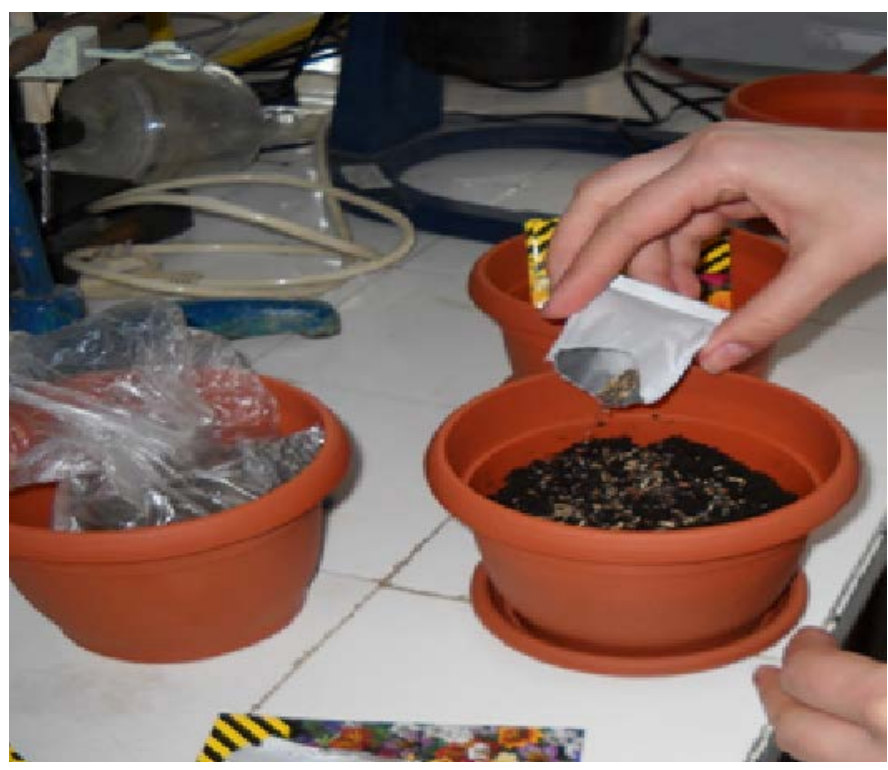

Figure 9. Planting plants (Tagetes patula). 


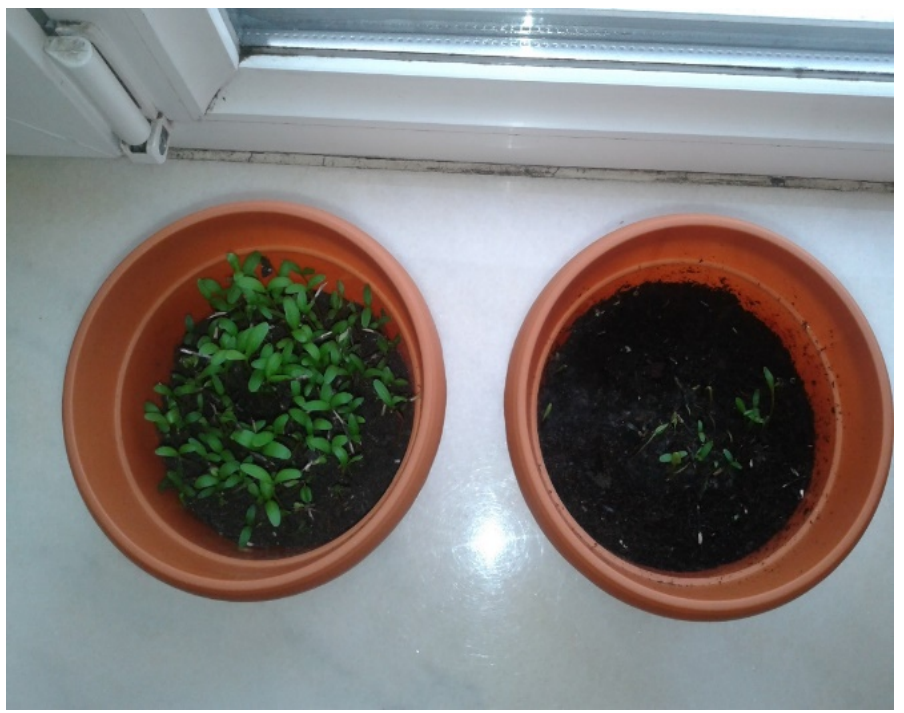

Figure 10. Behavior of plants in soil and peat polluted with biodiesel (Tagetes patula) to $20^{\circ} \mathrm{C}$ of determinations experiments).

The following were found:

1) All three pots had a growth of flowers with a density of these as follows: unpolluted soil 100 threads, flower soil polluted with biodiesel 30 threads and soil polluted with biodiesel 10 threads.

2) The flowers developed normally without supporting the growth with additives.

\section{Effects of Biodiesel Pollution on the Phytotechnical Characteristics of the Soil in the Lower Range Area}

Soils polluted with diesel and biodiesel were analyzed in terms of their behavior at various levels of pollution.

Thus, the following were found (Figure 11 and Table 3):

- PH increased with diesel pollution and decreased with biodiesel pollution,

- There is a decrease in salts due to diesel pollution and a very high increase due to biodiesel pollution,

- Carbonates decrease with biodiesel pollution,

- Humus is found only in diesel pollution,

- Potassium is less sensitive to diesel pollution but very sensitive to biodiesel pollution.

Following the analyzes performed, we can state that:

- Biodiesel degrades in a maximum of 2 weeks (30\%) and 1 month (99\%),

- There is a linear flow of biodiesel into the soil (the soil absorbs biodiesel),

- The most useful depollution treatments are those with biodegradable absorbent (dry peat) which ensures rapid degradation,

- No heat desorption treatments are required, as biodiesel is biodegradable,

- The soil absorbs more biodiesel than diesel, more 316\%,

- Using the naturals sorption of the elimination pollution. 
Table 3. Behavior of soil polluted with biodiesel and diesel (to $20^{\circ} \mathrm{C}$ of determinations).

\begin{tabular}{|c|c|c|c|c|c|c|c|}
\hline \multirow{2}{*}{ Soil type } & $\mathrm{pH}$ & Salt & Carbonates & Humus & $\mathrm{N}$ & $\mathrm{P}-\mathrm{al} / \mathrm{pH}$ & $\mathrm{K}-\mathrm{Al}$ \\
\hline & & $\mathrm{Mg} / 100 \mathrm{~g}$ soil & $\%$ & & & Ppm & Ppm \\
\hline Soil non polluted & 8 & 64.06 & 8.91 & 3.48 & 0.18 & 140.89 & 616 \\
\hline Soil polluted by $10 \%$ diesel & 8.17 & 63.68 & 8.68 & 4.92 & 0.25 & 136.78 & 606 \\
\hline Soil polluted by $20 \%$ diesel & 8.13 & 62.16 & 8.21 & 4.13 & 0.21 & 146.76 & 606 \\
\hline Soil polluted by $5 \%$ biodiesel & 6.46 & 134.98 & 7.74 & & & 129.20 & 550 \\
\hline Soil polluted by $10 \%$ biodiesel & 6.74 & 233.92 & 7.72 & & & 129.60 & 550 \\
\hline Soil polluted by $20 \%$ biodiesel & 6.83 & 274.72 & 7.50 & & & 132.61 & 550 \\
\hline Soil polluted by $30 \%$ biodiesel & 6.84 & 337.96 & 7.48 & & & 132.82 & 564 \\
\hline Soil polluted by $40 \%$ biodiesel & 7.13 & 805.08 & 7.27 & & & 44.15 & 584 \\
\hline
\end{tabular}

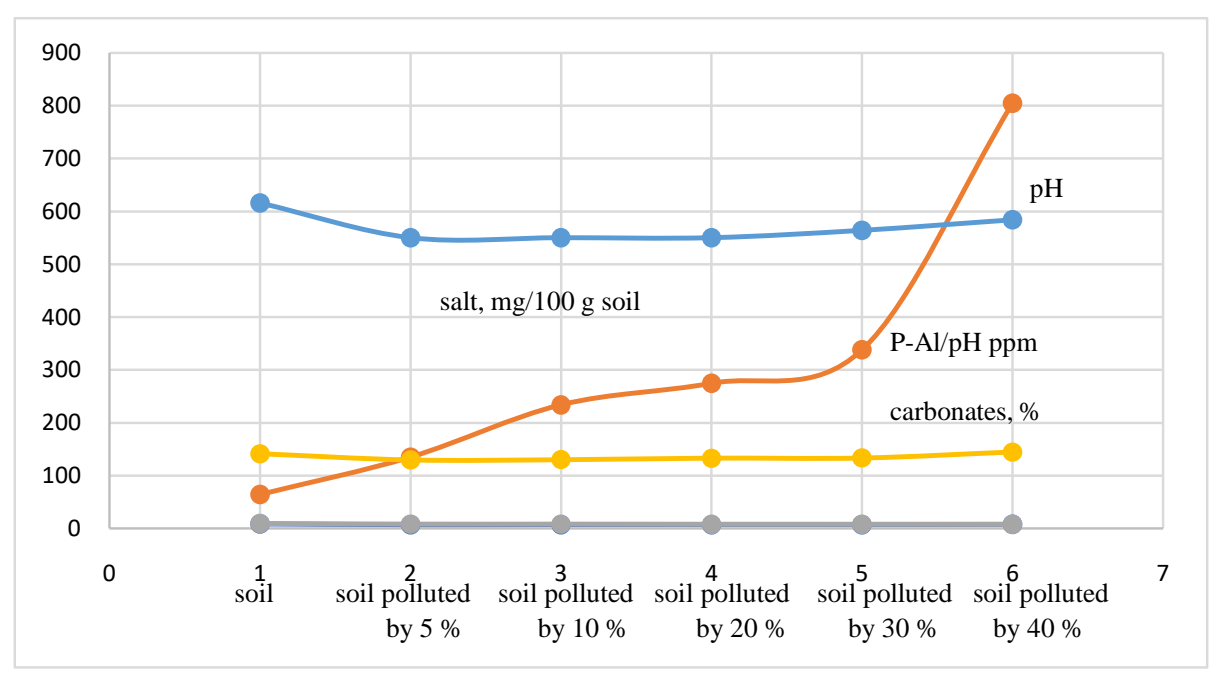

Figure 11. Behavior of soil polluted with biodiesel to $20^{\circ} \mathrm{C}$ of determinations).

\section{Conclusions and Recommendation}

In the case of a biodiesel pollution of the soil, it is absolutely necessary to intervene by:

1) Elimination of biodiesel leakage,

2) Recovery of biodiesel using sorbents,

3) Conducting surveys and analyzes to see the extent of pollution,

4) Stripping of contaminated soil and transporting it for treatment,

5) Restoration of soil affected by pollution.

\section{Conflicts of Interest}

The authors declare no conflicts of interest regarding the publication of this paper.

\section{References}

[1] Khan, N.F. A Comparison of Acute Toxicity of Biodiesel, Biodiesel Blends and Di- 
esel on Aquatic Organisms. https://www.ncbi.nlm.nih.gov/pubmed/17385594

[2] Hawrot-Paw, M., Wijatkowski, A. and Mikiciuk, M. (2015) Influence of Diesel and Biodiesel Fuel-Contaminated Soil on Microorganisms, Growth and Development of Plants. Plant, Soil and Environment, 61, 189-194. https://doi.org/10.17221/974/2014-PSE

[3] Adam, G. and Duncan, H. (2002) Influence of Diesel Fuel on Seed Germination. Environmental Pollution, 120, 363-370. https://doi.org/10.1016/S0269-7491(02)00119-7

[4] Yin, Z.H., Zhu, L.D., Li, S.X., Hu, T.Y., Chu, R.Y., Mo, F., Hu, D., Liu, C.C. and Li, B. (2020) A Comprehensive Review on Cultivation and Harvesting of Microalgae for Biodiesel Production: Environmental Pollution Control and Future Directions. Bioresource Technology, 301, 122804. https://doi.org/10.1016/j.biortech.2020.122804

[5] Živković, S. and Veljković, M. (2018) Environmental Impacts of the Production and Use of Biodiesel. Environmental Science and Pollution Research, 25, 191-199. https://doi.org/10.1007/s11356-017-0649-Z

[6] Russi, D. (2008) An Integrated Assessment of a Large-Scale Biodiesel Production in Italy: Killing Several Birds with One Stone? Energy Policy, 36, 1169-1180. https://doi.org/10.1016/j.enpol.2007.11.016

[7] Hawrot-Paw, M. (2011) Biomass of Living Organisms in Soil Cong Taminated with Diesel Oil and Subjected to Bioremediation. Zeszyty Naukowe Uniwersytetu Przyrodniczego we Wrocławiu-Rolnictwo, 98, 49-56.

[8] https://www.ebatco.com/laboratory-services/liquids/density-testing/

[9] ASTM D1298-99 (2005) Standard Test Method for Density, Relative Density (Specific Gravity), or API Gravity of Crude Petroleum and Liquid Petroleum Products by Hydrometer Method. https://www.astm.org/DATABASE.CART/HISTORICAL/D1298-99R05.htm

[10] ASTM D1665-98 (2009) Standard Test Method for Engler Specific Viscosity of Tar Products. https://www.astm.org/DATABASE.CART/HISTORICAL/D1665-98R09.htm

[11] https://www.thomassci.com/scientific-supplies/U-Tube-Viscometer 